\title{
The application of the cemented thickened/paste tailings backfill with large flow capacity in Chinese iron mines
}

\author{
AX Wu University of Science and Technology Beijing, China \\ XX Miao University of Science and Technology Beijing, China \\ HJ Wang University of Science and Technology Beijing, China \\ HZ Jiao University of Science and Technology Beijing, China \\ YM Wang University of Science and Technology Beijing, China
}

\begin{abstract}
The development of paste technology has been similar around the world, from non-ferrous and gold mines to other kinds of metal mines. In recent years, paste technology has rapidly spread to iron mines. Iron ore deposits in China are usually irregular, fractural and of low grade. Therefore, the managers have to use large scale mining to reduce the mining cost per unit; large scale backfill systems are required for the safe operation of large scale extraction. Consequently, backfill systems with a large flow capacity are used in iron mines.
\end{abstract}

The Lilou Iron Mine backfill capacity has reached $160-180 \mathrm{~m}^{3} / \mathrm{h}$ with an annual mining production of $7.5 \mathrm{~m} t$ ore, the filling cost of which is CNY 18-30 per tonne of extracted ore.

\section{$1 \quad$ The advantages of paste filling technology}

Paste or thickened tailings backfill is one of the latest technological advances in the mining industry (Jewell \& Fourie 2006).

Compared with other filling methods, the most extraordinary advantage of paste or thickened tailings is its high slurry concentration of generally more than $72 \%$. Some paste can even reach $80-82 \%$ (concentrations are not the same for different types of tailings). Paste generally has the following characteristics (Potvin et al. 2005):

- It usually consists of mill tailings as the base component.

- Particles finer than $20 \mu \mathrm{m}$ usually account for $15-20 \%$ by weight.

- Fine particles (5-10 $\mathrm{mm}$ ) usually account $0-15 \%$.

- Bleeding rate ranges from 3-5\%; slump ranges from $23-25 \mathrm{~cm}$.

- Yield stress should be approximately 100-200 Pa.

The paste backfill process includes four steps; tailings dewatering and thickening, materials mixing, pipeline transporting, stope barricade construction. For filling, whether it is thickened tailings or paste, it is best when it is in a state of slurry, as it can be delivered by gravity without segregating or bleeding in pipeline.

\section{The route from the non-ferrous mine to the iron mine of backfill}

Backfill mining method, with outstanding advantages of high recovery and low dilution, is an effective control to reduce the environmental impact of the underground activities (Xia 2011).

China commenced the trial of high concentration tailings backfill technology in Jinchuan (nickel) and Fankou lead mine in the 1980s, and a thickened tailings system in Donguashan Copper Mine in the 1990s. In the 
2000s, China saw the establishments of Tonglushan Copper Mine paste backfill system, Wushan Copper Mine paste backfill system, and more significantly, the Zhangmatun Iron Mine thickened tailings backfill system. Following the Zhangmatun Iron Mine, thickened tailings backfill systems have spread into iron mines, and has recently been applied in Lilou Iron Mine, Caolou Iron Mine, and Zhengjiapo Iron Mine (Liu et al. 2012; Yang et al. 2008).

\section{The necessity of iron mine paste filling system}

\subsection{Complicated deposits}

Compared with non-ferrous metals mines, iron deposits are characterised by large continuous orebodies, stable ore and host rock, shallow embedment and caving surface. However, with the large consumption of resources, sections with better mining conditions within the deposits are usually depleted, leaving behind those hard-to-excavate areas, which are located under villages, water strata and railway, or with soft broken rock, or of complicated shapes. In recent years, the mining operations for some of the new iron mines have been complicated. Some examples are as follows:

- Zhangmatun Iron Mine is deposited in an area of villages, farmland and the Baotu Spring stratum, which is the most famous spring in China (He 2011).

- Zhengjiapo Iron Ore occurs in an area of villages, farmland, and lies directly under the Quaternary aquifer (Han 2010).

- Zhaopingfang, Chenjiadian ore is located under the city of Yingkou. There is a river flowing right across the mine area. The Zhaopingfang area does not allow the construction of a tailings pond and process plant (Li et al. 2013).

- Laixin Iron Ore is crushed and liable to expansion coming into contact with water; the maximum exposed span is only $5 \mathrm{~m}$.

It is obvious the stoping and caving methods are no longer suitable for most new deposits, and the mining method using backfill has become widely spread in recent years.

\subsection{Large scale mining operation}

In contrast with the nonferrous metals deposits, iron ore deposits are characterised by large continuous reserves with large scale mining operation. The iron ore market also requires large scale mining to achieve economies of scale.

- The strike expansion of Caolou Iron Mine's main body is $2.4 \mathrm{~km}$; the average thickness is $53 \mathrm{~m}$; with local areas up to $130 \mathrm{~m}$; the depth is $130-208 \mathrm{~m}$. The deposit reserves are $100 \mathrm{~m} \mathrm{t}$. The production is $3 \mathrm{~m}$ t/year (Jiang 2008).

- Lilou Iron Ore has strike length of $4 \mathrm{~km}$, a thickness 6-120 $\mathrm{m}$ with an average of $42 \mathrm{~m}$. Its total reserves are $2.7 \mathrm{~m} \mathrm{t}$. The underground mining capacity is $7.5 \mathrm{~m} \mathrm{t} /$ year (Zhang 2012).

- The annual mining production of Dahongshan Mine is $5 \mathrm{~m} \mathrm{t}$.

- Zhouyoufang Mine's production is $4.5 \mathrm{~m}$ t/year (Zhou \& Huai 2013).

- Jilin Wudaoyangcha Iron Ore's designed production capacity is $10 \mathrm{~m} \mathrm{t} / \mathrm{year}$, however, its actual capacity has reached $5 \mathrm{~m} \mathrm{t}$ /year (Liu 2012).

- Sijiaying Iron Ore's mining capacity reached $15 \mathrm{~m}$ t/year with the backfill method (Wang et al. 2011). 


\subsection{Low grade iron ore}

The iron ore overseas are mostly of low phosphorus content and good quality, and generally at shallow depth, with a grade of $56-62 \%$. These deposits are suitable for open pit mining. However, the grade of qualified iron resources in China is about $40 \%$, accounting for about $20 \%$ of domestic iron ore production. The majority iron mines are of lower grade, such as:

- Liguanji Mine's geological grade is about 16. 5\% (Zhang \& Song 2009).

- Jilin Wudaoyangcha Iron Mine's grade is about 12.5\% (Yang et al. 2008).

Urgent need for advanced mining technology is called for to improve iron ore profitability in China.

In short, the fierce competition in the iron ore market pushes the mining enterprises to boost production, so as to achieve economies of scale and higher risk resistance. Under the pressure of environmental protection, work safety and economic benefits, the backfill method has become an inevitable choice for mining enterprises. Meanwhile, in order to ensure the balance of mining and filling, large flow capacity transportation systems should be built for large scale mining enterprises.

\section{$4 \quad$ Iron ore backfill characteristics - large flow capacity, low cost}

Iron mines typically operate with larger production than non-ferrous mines, which calls for a larger backfill capacity. Generally, non-ferrous mining production is lower than $200 \mathrm{t} / \mathrm{year}$, with corresponding filling capacity between $60-80 \mathrm{~m}^{3} / \mathrm{h}$. While the production for iron mines is generally $4-10 \mathrm{~m}$ t/year, requiring large flow filling system with capacity about $150-300 \mathrm{~m}^{3} / \mathrm{h}$ (Liu 2012).

For example, Lilou Iron Mine has a production of $7.5 \mathrm{~m}$ t/year; considering a conventional backfill system with capacity of $60-80 \mathrm{~m}^{3} / \mathrm{h}$, at least 10 sets of deliveries would be needed, whilst if large flow capacity $\left(180 \mathrm{~m}^{3} / \mathrm{h}\right)$ filling system is employed, only $3-4$ sets of deliveries would be required. This would greatly improve mining efficiency and reduce the capital and operating cost (Zhang 2012).

Many industrial applications have proved that increasing filling capacity directly reduces filling cost. Caolou Iron Mine's backfill cost is only CNY 18/t of ore mined, with a flow capacity of $320 \mathrm{~m}^{3} / \mathrm{h}$ (Jiang 2008). Zhengjiapo Iron Mine cost is CNY 24/t ore with a flow capacity of $160 \mathrm{~m}^{3} / \mathrm{h}$ (He 2011).

\section{$5 \quad$ Case study}

\subsection{Mining method}

The Lilou iron orebody extends $3.4 \mathrm{~km}$ from north to south, with a width of $500 \mathrm{~m}$, and a depth of 90-862 m.

The main mining method is shallow-hole room and pillar mining with subsequent filling, with level height being $40 \mathrm{~m}$, as shown in Figure 1. The long axis of stope is perpendicular to the orebody strike. The stope width is $8 \mathrm{~m}$, height is less than $14 \mathrm{~m}$, and length is that of the orebody thickness. The roof pillar thickness is $6 \mathrm{~m}$. 


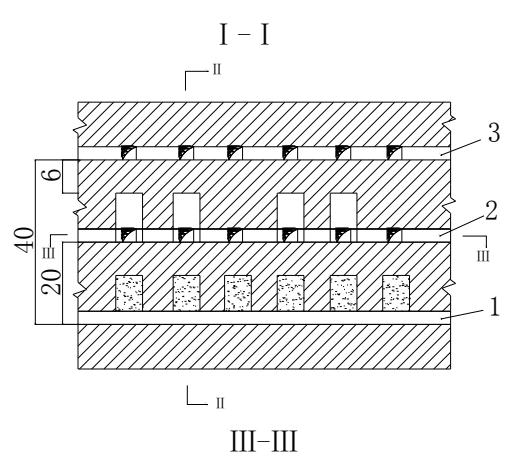

6

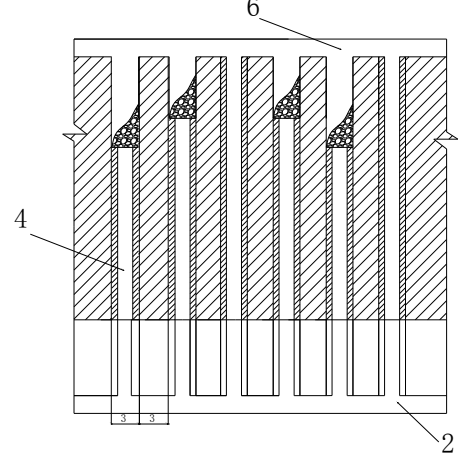

II - II

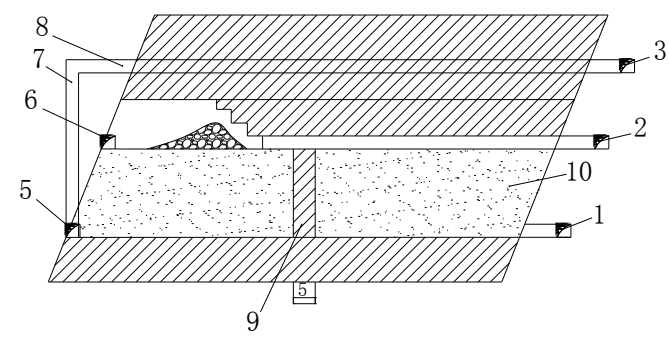

1.-200m level foot wall drift;

2.-180m level foot wall drift;

3.-160m level foot wall drift;

4.under cut drift; 5.-200m level hanging

wall ventilation drift;

$6.180 \mathrm{~m}$ level hanging wall ventilation

drift;

7.Ventilation Shaft; 8.Ventilation Cross

9.Safefy Pillar; 10.Backfill Body

\section{Figure 1 Shallow-hole room and pillar mining with subsequent filling}

\subsection{Thickened tailings backfill system}

The backfill slurry consists of tailings that has been thickened by two non-rake thickeners and a two-stage mixing. Thickened tailings are discharged from the non-rake thickeners to a double-axis mixer. Cement is conveyed to the mixer by a screw conveyor. The slurry out from the double-axis mixer is then transported into a high rate activation mixer. The final backfill slurry is of $72-74 \%$ weight concentration and delivered to underground stopes through boreholes and pipelines. The process is shown in Figure 2 . The flow capacity is $160-180 \mathrm{~m}^{3} / \mathrm{h}$. The system is comprised of two non-rake thickeners, one cement silo, one set of mixers, two boreholes and relevant control systems.

- The tailings slurry is pumped into the thickener; diameter $15 \mathrm{~m}$, height $10 \mathrm{~m}$, and volume $2,020 \mathrm{~m}^{3}$.

- The binder is ordinary Portland cement (R28 $=32.5 \mathrm{Mpa}$ ). The cement silo has diameter of $6 \mathrm{~m}$, height $10 \mathrm{~m}$, and volume $330 \mathrm{~m}^{3}$, capable of fulfilling daily cement amount.

- There are four backfill boreholes in the system (two of which are backups). The pipelines delivering backfill slurry to the underground stopes are connected to the surface plant by boreholes. The pipe in the borehole is a D180 $\times 14$ ceramic compound steel pipe, and the pipe in the underground drift is a PF180 steel composite pipe.

- Backfilling is conducted immediately after block excavation. Barricade construction is the most important work, which isolates the area to be filled, preventing backfill slurry from flowing into the tunnels. 


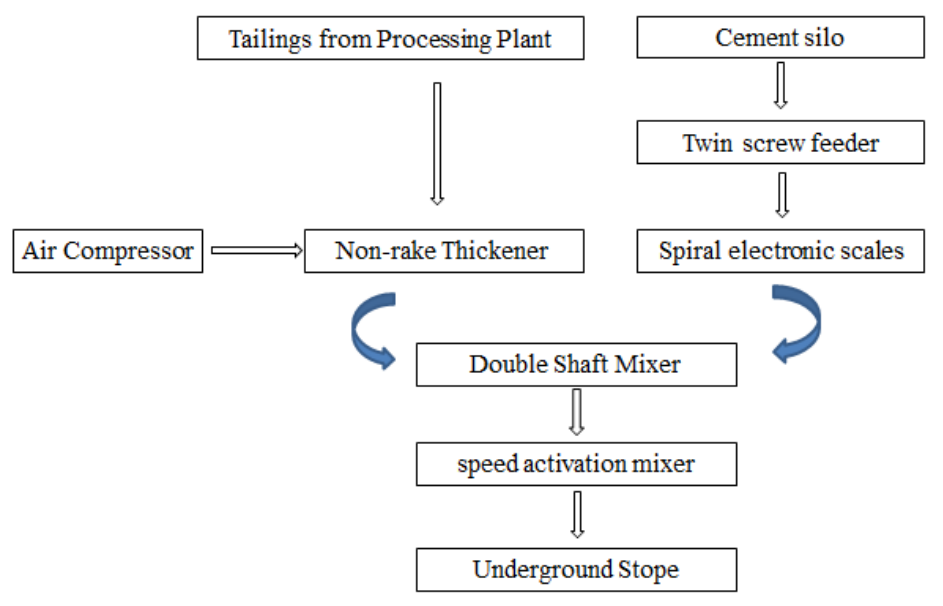

Figure 2 Sketch for cemented thickened tailings backfill system

The system operating parameters are shown in Table 1.

\section{Table 1 System operating parameters}

\begin{tabular}{lcc}
\hline Items & Unit & Value \\
\hline Flow capacity & $\mathrm{m}^{3} / \mathrm{h}$ & $160-180$ \\
Concentration & $\%$ & $72-74$ \\
Continuous operation time & $\mathrm{h}$ & $10-12$ \\
The maximum quantity one time & $\mathrm{m}^{3}$ & $1,600-1,800$ \\
Cement:tailings ratio & & $1: 4-1: 10$ \\
Unconfined compressive strength (UCS) & $\mathrm{MPa}$ & $0.78-4.2$ \\
\hline
\end{tabular}

\subsection{Underground filling arrangement}

The first three stopes for backfill is 16-1\#, 16-3\#, 16- 5\# at -200m level. Seven barricades are arranged in the three stopes. The barricade should be set $3 \mathrm{~m}$ away from the stope boundary, where the drift dimension is small and surrounding rock is stable, as shown in Figure 3. The barricade is reinforced with C20 concrete. The barricade structure is shown in Figure 4.

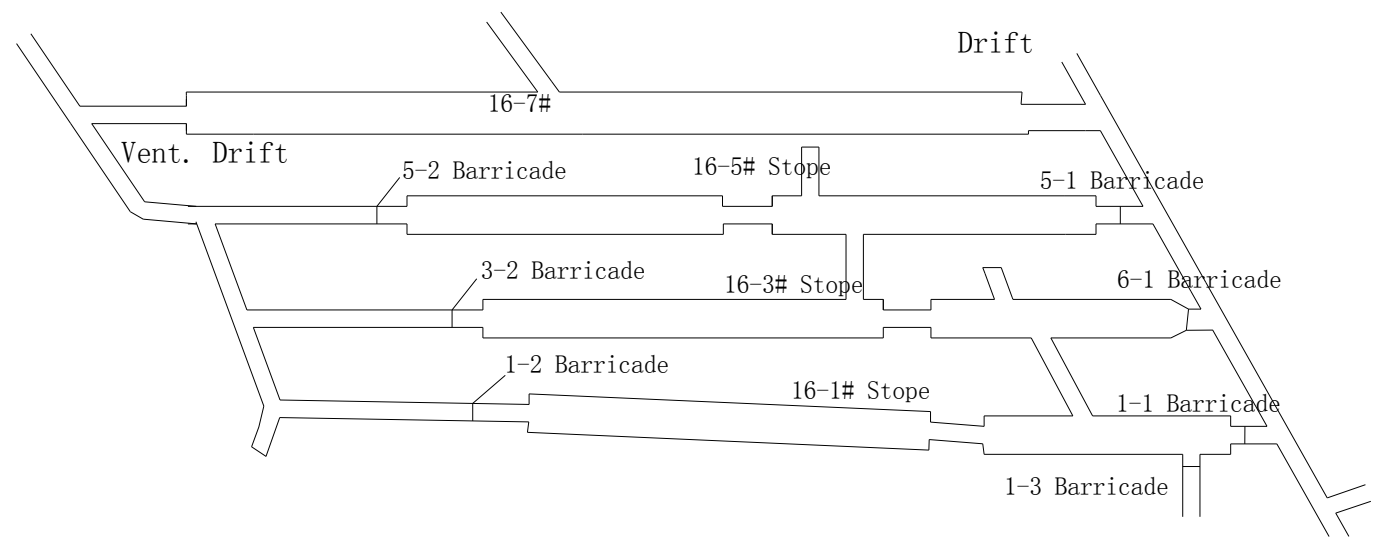

Figure 3 The barricades arrangement of -200m level 


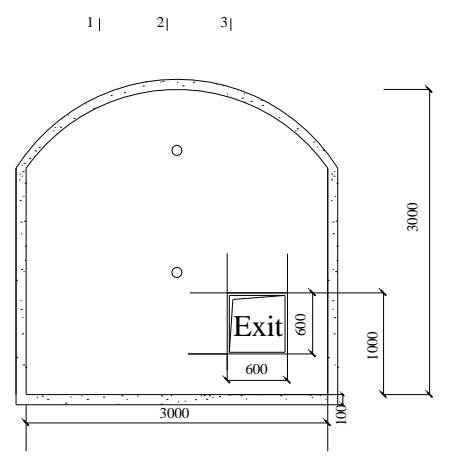

The fixture arrangement Drainage Tube

The exit seal method
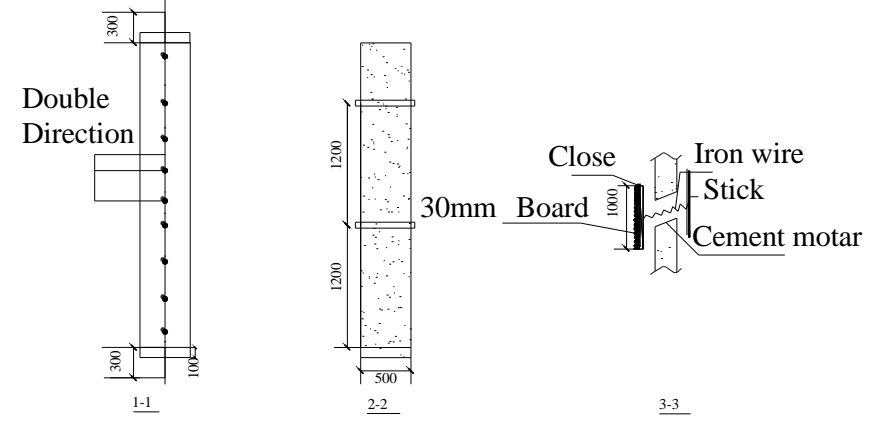

Figure 4 The structure of the underground barricade

The stope filling is carried out in several stages to prevent slurry bleeding accidents and reduce slurry pressure on barricades. The filling procedure is generally as follows; the lower $6 \mathrm{~m}$ of stope is filled by slurry of cement:tailings ratio of $1: 4$, the upper $8 \mathrm{~m}$ of stope is filled by slurry of cement:tailings ratio of $1: 8$. The filling operation is implemented every $1 \mathrm{~m}$ of backfill height, the next operation is conducted when the former backfill layer consolidates. The backfill cost is only CNY 18-30/t of ore mined.

The mining practice has proven that such filling method is able to ensure recovery rate of $85 \%$ and economic benefits of more than CNY 50 m annually.

\section{Conclusions}

Iron ore mining in China has the following characteristics:

- Complex geological conditions lead to difficulties in mining operations. To meet technological and market requirements, large scale mining is necessary for those newly built low grade iron mines. Therefore, the large flow backfill capacity becomes an inevitable choice for low cost operation of iron mines.

- As the application of backfill system becomes increasingly mature, thickened tailings/paste filling system has spread into China's iron mines, with more than a dozen of iron mines utilising high concentration/paste filling system.

- The Lilou Iron Mine uses shallow-hole room and pillar mining with subsequent filling; the stope width is $8 \mathrm{~m}$, height is $14 \mathrm{~m}$; the production capacity is 7.5 million t/year. The mine has built a cemented thickened tailings backfill system, with a flow capacity reaching $160-180 \mathrm{~m}^{3} / \mathrm{h}$. The slurry concentration is $72-74 \%$, the cement:tailings ratio is $1: 4$ to $1: 10$, the UCS of backfill at 28 days is $0.78-4.2 \mathrm{Mpa}$. The backfill cost per tonne of ore is CNY 18-30.

\section{References}

Han, B, Li, F \& Yuan, X 2010, 'Application and prospect of cut-and-fill mining method in iron mine', Yunnan Metallurgy, vol. 39, no. 1, pp. 23-6.

$\mathrm{He}, \mathrm{H}$ 2011, 'Application progress of filling techniques in iron mine over the past ten years', Engineering Construction, vol. 43, no. 4, pp. 28-32.

Jewell, RJ \& Fourie, AB (eds) 2006, Paste and Thickened Tailings - A Guide, 2nd edn, Australian Centre for Geomechanics, Perth.

Jiang, F 2008, 'Study of tailings ref ill technology in Caolou Iron Ore Mine', Mining Engineering, vol. 6, no. 1, pp. 28-30.

Li, J, Zhang, Z, Niu, W, Chen, J, Wang, R, Qiu, J, Xin, G, Zhang, S, Liu, X \& Sun, X 2013, 'Study on unclassified tailings cementing filling test for super large iron mine', Nonferrous Metals, vol. 65, no. 3, pp. 4-7.

Liu, B, Zheng, L, Bin, Y \& Chen, Z 2012, 'Research and application of total tailings backfilling technology for difficult to mine orebody in Zhao'anzhuang Iron Mine', Nonferrous Metals, vol. 64, no. 1, pp. 17-58.

Liu, X 2012, 'Practice of stoping and filling in mining of China's iron deposits', Mining Research and Development, vol. 32, no. 6, pp. 7-9.

Potvin, Y, Thomas, EG \& Fourie, AB (eds) 2005, Handbook on Mine Fill, Australian Centre for Geomechanics, Perth. 
Wang X, Yao, W, Wang, H, Qiao, D, Cheng, W \& Zheng, L 2011, 'The directions of R\&D on backfill with waste rock and total tailings in underground mine', China Mining Magazine, vol. 20, no. 9, pp. 76-9.

Xia X, 2011, 'The research on key techniques of mine construction in oversize underground iron mines', PhD thesis, China Mining University.

Yang, Z, Hou, K \& Qiao, D 2008, 'Present Application situation of cut-and-fill mining method and its development trend', Modern Mine, vol. 468, no. 4, pp. 1-5.

Zhang, \& Song, W 2009, 'Discussion on the current state of backfill mining from the domestic and foreign development', China Mining Magazine, vol. 18, no. 12, pp. 59-62.

Zhang, L 2012, 'Application of whole tailings cement filling technology in Lilou iron mine', Nonferrous Metals, vol. 64, no. 2, pp. 17-20.

Zhou, Z \& Huai, L 2013, 'The application of backfill mining method in Zhouyoufang Iron mine', Modern Mining, vol. 527, no. 3, pp. 87-9. 
